\title{
Sekulariseringen som vilkår for kirkens arbejde $^{1}$
}

\author{
Lektor Hans Raun Iversen
}

\begin{abstract}
Secularization can be seen as a part of the modern differentiation of spheres in society or as a result of a regression of religious beliefs and practices among common people. According to Taylor's opus magnum A Secular Age (2007) the process of secularization has four tracks of development: Most fundamental is (1) disembodiment, social disembeddedness and thereby the excarnation of religion. To this is added (2) a shift from porous to buffered selves, (3) the dissolution of holiness and (4) the existential acceptance of an immanent frame. For the individual, secularization means moving from a religiously authorized, integrated world into an open world with broken horizons for human identity. Secularization is thus not primarily about the disappearance of religion but about radical new conditions for human life - and hence for the work of the church. This applies in specific ways to the specific case of Denmark.
\end{abstract}

Key words: Secularization - secularity - secularism - A Secular Age ambivalence - church work.

\section{Sekularitet, sekularisme og sekularisering}

Der findes i det danske samfund en voksende radikal sekularitet $\mathrm{i}$ betydningen totalt fravær af religiøs praksis og i det hele taget manglende sans for og kendskab til religiøs tankegang i større og større dele af samfundet og hos et voksende mindretal af befolkningen. Med tilslutning fra blot fem pct. af befolkningen er ateismen ikke nogen stor succes, men der findes i dag også mennesker, for hvem det aldrig har været aktuelt at tænke på, om de tror på Gud. ${ }^{2}$ På samme måde er der et stigende antal unge, der ikke beder, ikke fordi de ikke har lyst,

1. Med hjertelig tak til deltagerne og bidragyderne på efteruddannelseskurset af samme navn efteråret 2008 på Københavns Universitet og januar 2009 på Teologisk Pædagogisk Center, Løgumkloster.

2. Phil Zuckerman, Samfund uden Gud. En amerikaner ser på religion i Danmark (Århus: Forlaget Univers 2008), 124-127. 
men fordi de aldrig har hørt om bøn som en menneskelig mulighed. ${ }^{3}$ Et sådant øjensynligt næsten totalt fravær af religion betegner en ny udvikling efter flere generationer med nedprioritering af religiøs praksis. Er sekulariseringen aldrig så meget begrænset til dele af befolkningen i Vesteuropa ${ }^{4}$ udgør den i det mindste hér en anderledes horisont for den personlige selvforståelse - og dermed et anderledes vilkår for kirkens arbejde. Spørgsmålet, der skal drøftes her, er derfor, hvad forskellige former for sekularitet dækker over som livsvilkår.

Selv om forhenværende statsminister Anders Fogh Rasmussen som den første af slagsen - gik direkte ind i kampen for, at religionen skal "ud af det offentlige rum", 5 bidrog han i første omgang til disse års voldsomt overdimensionerede, symbolpolitiske debat om religion i det offentlige rum. ${ }^{6}$ Men i anden omgang har statsministeren og hans formodede flertal af ligesindede politikere magt til at trænge religionen tilbage med politiske tiltag - $\mathrm{fx}$ i kampen mod drenges omskærelse og kvinders tørklæder. Man kan ligeledes afskære tilskud til de former for aktivitet, fx uddannelse, som potentielt har med religion at gøre, som det fx skete med Undervisningsministeriets brev af 2 . oktober 2008, hvor man afslog oprettelse af en ny professionsbachelor i Kristendom, Kommunikation og Kultur (bl.a. m. h. p. sognemedhjælperstillingen i folkekirken) med følgende argumentation:

\begin{abstract}
Der er lagt til grund for afgørelsen, at de kirkelige organisationers behov for uddannet arbejdskraft til formidling af kristendom mv. ikke skal dækkes af uddannelser efter Undervisningsministeriets lovgivning. Forskningsbaseret viden om kristendommen kan opnås gennem universiteternes teologiske uddannelser, der udbydes på såvel bachelor- som kandidatniveau, mens undervisning i de fag, der specifikt retter sig mod arbejdet som præst i den danske folkekirke, tilbydes på pastoralseminariet, som efter- og videreuddannelse til teologiske kandidater. Yderligere behov for uddannede til formidling af kristendommen bør efter Undervisningsministeriets vurdering varetages af de kirkelige organisationer selv.
\end{abstract}

Hvad vi møder her, er en form for sekularisme, in casu en politik, som søger at privatisere religion. Skønt uddannelsen anbefaledes

3. Samtaler med københavnske præster om erfaringer med konfirmander foråret 2008.

4. Grace Davie, Europe - the exceptional Case. Parameters of Faith in the Modern World (London: Darton Longman \& Todd 2002).

5. Jf. Sammenhangskraften. Replikker til Fogh, red. Peter Lodberg (Århus: Forlaget Univers 2007).

6. Mattias Rosenfeldt, "Hvor meget fylder religion?", Kritisk Forum for Praktisk Teologi 109 (2007), 31-47. 
stærkt af de ansøgende professionshøjskoler (VIA i Århus og METROPOL i København), ligesom aftagerne (Landsforeningen af Menighedsråd, biskopperne, de frie kirkelige organisationer og frikirkerne) ønskede uddannelsen til et ansættelsesområde på ca. 1200 kirkelige stillinger, blev ansøgningen afslået. Ikke fordi den var dårlig eller uden arbejdsmarked. Ej heller fordi den var "religiøs", for den er tænkt som en regulær professionsuddannelse på linie med andre af slagsen, fx læreruddannelsen. Uddannelsen blev afslået, fordi den tog sigte på kirkelig beskæftigelse, som potentielt kan være med til at støtte religionens stilling i Danmark! Alt kan man få statsligt støttet uddannelse til, hvis der ellers er et arbejdsmarked, blot ikke kirkelig virksomhed, medmindre man skal være præst. Henvisningen til de teologiske fakulteter er lidt patetisk i sammenhængen: man tør ikke røre ved det bestående, men siger nej til en uddannelse i kristendomskundskab, som er tænkt som en genoptagelse af den indsats for kompetence til kristendomsundervisning, som så sent som i begyndelsen af 1970'erne lå i seminarernes kristendomsfag, Lærerhøjskolens cand.pæd. i kristendomskundskab og universiteternes cand. mag i kristendomskundskab, der nu alle er nedlagt eller ændret til ubrugelighed, når det gælder kirkens behov for kompetente lærere i kristendom. At den konkret-strategiske begrundelse antageligt er angst for, at "andre" - fx muslimer eller scientologer - skal komme med en lignende uddannelsesplan, gør principielt hverken fra eller til. Holdningen er netop principiel: Staten støtter alle former for uddannelse til alle former for (lovligt) arbejde, dog ikke uddannelser, der primært vil levere arbejdskraft til et kirkeligt eller religiøst arbejdsmarked. ${ }^{7}$

Det at skabe sekularitet eller et sekulært rum, fx i de af statens støttede uddannelser, er udtryk for et stykke sekularistisk politik, eller en bestemt form for sekularisme. Sagt med Martin Riesebrodt: "Säkula-

7. En fornyet udgave af ansøgningen passerede Undervisningsministeriets politiske screening i juni 2009. Om det var ændringerne i ansøgningen (med mere vægt på andre religioner og ansættelsesmuligheder uden for kirkeligt regi) eller lobbyarbejdet, der gjorde forskellen, vides ikke. Eksemplet viser dog, at der er grænser for sekularismen i dansk politik, selv om de er svære at finde - og sikkert også vanskelige at trække - $\mathrm{i}$ en situation, hvor religion optræder som symbolpolitisk kastebold - foruden i grundlovens paragraf 4. Undervisningsminister Bertel Haarder godkendte endelig uddannelsen ultimo december 2009 med følgende udtalelse på Undervisningsministeriets hjemmeside: "I min tid som kirkeminister gjorde biskopperne mig opmærksom på et behov for, at sognemedhjælperne i folkekirken får en reel uddannelse, der klæder dem godt på til deres arbejde. Den nye uddannelse kombinerer tradition med moderne organisationsværktøjer og teorier på en spændende måde. Det har glædet mig at godkende den og fire andre nye videregående uddannelser, der på hver sin måde dækker nogle vigtige behov i samfundet." Her har vi et af de senere års meget få eksempler, hvor kristendommen - og grundlovens $₫ 4$ - er taget alvorligt i politisk praksis. 
risierung stellt keinen metaphysisch vorgegebenen historischen Prozess dar, sondern wird in der Regel durch staatliche Säkularisierungspolitik hervorgebracht." 8 Riesebrodt foretrækker at bruge "sekularisering" om den politisk bestemte sfæreopdeling, hvor religionen lukkes ude af bestemte samfundssektorer (Riesebrodt 2007, 246). Heroverfor står affortryllelsen af bevidsthederne og kirkernes svindende opbakning, som ikke automatisk følger af den politisk indførte "sekularisering". Bag det hele ligger dog under alle omstændigheder en lang historisk sekulariseringsproces, som dels i høj grad er og har været politisk styret, dels også udgør mulighedsbetingelsen for, at sekularitet kan opstå, og for at der kan føres en sekularistisk politik a la den danske.

Skal vi bag om vores nuværende situation, må vi forstå sekulariseringsprocessen som historisk fænomen. Som sammenfattende udtryk for sekulariseringsstudierne omkring $1980^{9}$ står Anders Pontoppidan Thyssens historisk-sociologiske kortlægning af den enevældige, statskirkelige enhedskulturs opløsning, hvor sekularisering dækker over “...statskirkeordningens nedbrydning og forfald, og dermed opløsningen af den statsintegrerede, almindeligt accepterede statsinstitutionelle religiøsitet". ${ }^{10}$ På den personlige tilværelsesforståelses og livsudfoldelses plan er sekulariseringsprocessens successive fremadskriden afdækket i generationsbeskrivelser af en række litterære forfattere gennem de sidste 50 år: Tage Skou-Hansen ${ }^{11}$, Kirsten Thorup ${ }^{12}$, Jens Smærup Sørensen ${ }^{13}$, Pia Fris Laneth ${ }^{14}$ og ikke mindst Vibeke Grønfeldt ${ }^{15}$, der lader sin hovedperson, Agate, tænke således - før sekulariseringens gennemslag på landet $\mathrm{i}$ forbindelse med den anden industrielle revolution efter anden verdenskrig: "Alting i verden hænger sammen. Sådan er indretningen” (Grønfeldt 2008, 109).

8. Martin Riesebrodt, Cultus und Heilsversprechen. Eine Theorie der Religionen (München: Verlag C.H. Beck 2007), 253.

9. Jf. især Agnete Brink, Michael Schelde og Erik Bredmose Simonsen, Sakularisering $i$ Danmark. En teoretisk analyse og historisk beskrivelse af sakulariseringsprocessen fra omkring 1870 til vor tid (Århus: Anis 1984).

10. A. Pontoppidan Thyssen, "Sekulariseringsprocessen i Danmark" [1980], Grundtvig og den grundtvigske arv. Afhandlinger (København: Anis 1991), 343.

11. De nøgne traer 1957, Tredje halvleg 1971, Medløberen 1973, Den härde frugt 1977, Over stregen 1980, På sidelinien 1996 - samt Det midlertidige fallesskab 1972.

12. Lille Jonna 1977, Den lange sommer 1979, Himmel og helvede 1982 og Den yderste granse 1987.

13. Markedage 2007.

14. Lillys Danmarkshistorie. Kvindeliv i fire generationer 2006.

15. Mindet 2005, I min tid 2006 og Indretningen 2008. 
En oplevelse af tilværelsen som på forhånd “indrettet” og indlejret i en urokkelig religiøst sanktioneret lovmæssighed findes næsten ikke mere. Her har "sekulariseringen" sat sig afgørende igennem. Selv om en historisk-sociologisk blotlægning af sekulariseringsprocessen er vigtig, er den ikke tilstrækkelig, hvis man vil forstå, hvad sekularisering dækker over som aktuelt livsvilkår - og som vilkår for kirkeligt arbejde i dag. Akkurat til det formål er Charles Taylors monumentale A Secular Age en meget stor hjælp. ${ }^{16}$ På linie med Thyssen anskuer Taylor i udgangspunktet sekulariseringen som en historisk proces, hvor "disenchantment brought a new uniformity of purpose and principle." Sekularisering drejer sig således for Taylor om ændringen $\mathrm{i}$ "the way we collectively imagine, even pre-theoretically, our social life in contemporary Western world"17. Han ser således på sekulariseringen som en ændring i det fællesfolkelige, mentale beredskab.

Taylor tager udgangspunkt i tre forskellige forståelser af sekularisering, hvoraf de to første flittigt anlægges af religionssociologer ${ }^{18}:$ 1) Sekularisering som frigørelsen af staten og dens institutioner fra religionen (jf. Riesebrodt 2007) og 2) sekularisering som svind i religiøs tro og praksis i befolkningen og endelig 3) sekularisering som forandrede vilkår for livstolkningen, som er blevet et ambivalent, dvs. et reflekteret og problematiseret valg, hvor man ofte lige så godt kan vælge det ene som det andet. Taylors interesse er at beskrive denne tredje forståelse af sekularisering. Han gør begrebet "fullness" til udgangspunkt for sin analyse: "Somewhere, in some activity, or condition, lies a fullness, a richness; that is, in that place (activity or condition), life is fuller, richer, deeper, more worth while, more admirable, more what it should be" (Taylor 2007,5). Som god katolik forestiller Taylor sig øjensynligt, at oplevelsen af livsfylde, fullness, primært men ikke eksklusivt har ligget og bør kunne ligge i kirken. Til oplevelsen af "fullness" knyttes såvel en afhængighedsfølelse, en umiddelbar følelse af sikkerhed og en form for transcendenserfaring - ofte i forbindelse med rituel praksis og oplevelse af det hellige i kirken, naturen, samfundet og/eller livets vilkår. Fra vor tid kan Taylor øjensynligt bedst finde fullness-oplevelser hos helt særlige personer i helt særlige situati-

16. Charles Taylor, A Secular Age (London: The Belknap Press of Harvard University 2007). En bog på 874 sider og en omfattende efterfølgende debat (med snart 2 mill. hits på Google) bringer adskilligt stof, som her må lades unævnt. På dansk foreligger af Taylor Modernitetens ubehag - Autenticitetens etik. Indledning ved Morten Raffnsøe-Møller (Århus: Forlaget Philosophia 2002). Taylors arbejdsform er kredsende og essayistisk, ikke systematisk og begrebskonsistent. En mere sammenfattende redegørelse for hans position er således et projekt i sig selv.

17. Taylor (2007), 146.

18. Jf. de udførlige oversigter og debatter mellem positionerne i After Secularization, The Hedgehog Review 8/Volume 1-2, 2006. 
oner som i den unge, senere berømte benediktinermunk, Bede Griffiths sanseudvidede oplevelse af naturen som paradisets have (s. 5) og Vaclac Havel fængselsoplevelse af at være "struck by love" (s. 728-9).

Interviewmaterialet bag bogen I hjertet af Danmark ${ }^{19}$ demonstrerer også, hvordan konkrete oplevelser, kan blive til identitetsskabende erfaringer. Meget tyder på, at Svend Bjerg har ret i, at vejen til tro går gennem oplevelse, der bliver til erfaring gennem refleksion - mens ikke-tro tilsvarende ofte bunder i mangel på oplevelser, der har kunnet sætte sig som troserfaringer. ${ }^{20}$ Hos de fleste mennesker er sådanne erfaringer i dag i bedste fald punktuelle, momentane og fluktuerende, når og hvor det lykkes for os at være til stede $\mathrm{i}$ vore kroppe, så tilværelsen glimtvis får sammenhæng - måske, men ikke nødvendigvis støttet og tolket af et religiøst og/eller kulturelt symbolunivers.

\section{Taylors analyse af sekulariseringsprocessen}

Jeg har forsøgt at fremstille faserne og hovedelementerne i Taylors analyse af de sidste 500 års sekulariseringsproces i det følgende skema, som samtidig giver nogle foreløbige antydninger af, at processen i Danmark generelt har været lidt langsommere og på nogle punkter betydeligt svagere end i Frankrig, England og Tyskland, som Taylor primært refererer til:

19. Peter Gundelach, Hans Raun Iversen og Margit Warburg, I hjertet af Danmark. Mentaliteter og institutioner (København: Hans Reitzels Forlag 2008).

20. Svend Bjerg, Tro og erfaring (København: Anis 2006). 
Taylor om sekulariseringsprocessens stadier i Vesteuropa gennem 500 år

\begin{tabular}{|c|c|c|}
\hline Faserne & $\begin{array}{c}\text { Udviklingen i Frankrig/England/ } \\
\text { Tyskland }\end{array}$ & Danmark \\
\hline \begin{tabular}{|l|} 
Reformationen \\
\end{tabular} & $\begin{array}{l}\text { a) Brud med hierarki af hellig- } \\
\text { hed. } \\
\text { b) Demokratisering af adgang til } \\
\text { Gud og bibel. } \\
\text { c) Begrænsning af kirkens betyd- } \\
\text { ning i kraft af læren om Guds } \\
\text { enehandling i frelsen ved tro } \\
\text { alene. } \\
\text { d) Ecclesia semper reformanda } \\
\text { som pioner for kommende re- } \\
\text { volutioner. }\end{array}$ & $\begin{array}{l}\text { Re-formgivning af } \\
\text { kirken med fremhæ- } \\
\text { velse af retfærdiggø- } \\
\text { relse af tro. Uklar- } \\
\text { hed i synet på forhol- } \\
\text { det mellem tro og } \\
\text { gerninger. }\end{array}$ \\
\hline Civil & $\begin{array}{l}\text { a) Hele samfundet skal nå fælles } \\
\text { dannelse. } \\
\text { b) Den naturlige lov er de af for- } \\
\text { nuften tolkede naturlove. } \\
\text { c) Det religiøses stærke antistruk- } \\
\text { tur (fx karnevalet) afskaffes. }\end{array}$ & $\begin{array}{l}\text { Selv om der er ansat- } \\
\text { ser, især i rationalis- } \\
\text { men, kan man spør- } \\
\text { ge, om Danmark } \\
\text { først efter år } 2000 \\
\text { har fået et eksplicit } \\
\text { sekulært civilisations- } \\
\text { ideal? }\end{array}$ \\
\hline Dei & $\begin{array}{l}\text { a) Gud, dyd og udødelighed. } \\
\text { b) Fornuftighed og nytte. } \\
\text { c) Upersonlige naturlove. } \\
\text { d) Kunst som menneskers skabel- } \\
\text { se, modsat kunst som efterlig- } \\
\text { ning af det af Gud skabte. } \\
\text { e) Darwin ryster design- og for- } \\
\text { synstankerne. }\end{array}$ & 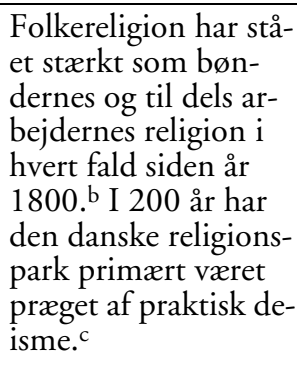 \\
\hline Human & $\begin{array}{l}\text { a) De frie, selvberoende indivi- } \\
\text { der. } \\
\text { b) Kristendom uden Gud, men } \\
\text { med universalisme. }\end{array}$ & $\begin{array}{l}\text { Kulturradikalismen } \\
\text { og den sekulære hu- } \\
\text { manisme har kun op- } \\
\text { nået begrænset folke- } \\
\text { lig udbredelse. }\end{array}$ \\
\hline \begin{tabular}{|l|} 
Mobiliseringen \\
\end{tabular} & $\begin{array}{l}\text { a) Fra kirker til denominationer. } \\
\text { b) Det fælles bagtæppe krakelerer } \\
\text { under konkurrerende tolk- } \\
\text { ningshorisonter. } \\
\text { c) Du kan kun blive salig i den } \\
\text { religion, du selv har valgt. }\end{array}$ & $\begin{array}{l}\text { Enhedssamfundet } \\
\text { opløsning fra vækkel- } \\
\text { serne over arbejder- } \\
\text { til kvindebevægelse } \\
\text { og ungdomsoprør er } \\
\text { velbeskrevet af Thys- } \\
\text { sen. }{ }^{\text {. }}\end{array}$ \\
\hline
\end{tabular}




\begin{tabular}{|c|c|c|c|}
\hline Autenticiteten & a) & $\begin{array}{l}\text { Sandt og ægte er det, den en- } \\
\text { kelte oplever som ægte for sig } \\
\text { selv eller for en anden author, } \\
\text { dvs. førsteperson, som man } \\
\text { kan identificere sig med. } \\
\text { Kristendomsbrugen bliver fri- } \\
\text { sat og personlig (kristen på } \\
\text { min egen måde). } \\
\text { At Gud er død (som ontolo- } \\
\text { gisk fundament), sætter ikke } \\
\text { gudstanken ud af spil. }\end{array}$ & $\begin{array}{l}\text { Folkekirken går fra } \\
\text { luthersk minimalis- } \\
\text { me til teologisk } \\
\text { mangfoldighed. Fol- } \\
\text { ket satser på (præ- } \\
\text { sternes) vikarierende } \\
\text { tro og individuel tro } \\
\text { med forbehold.e }\end{array}$ \\
\hline
\end{tabular}

a. "The irony is perhaps compounded, when we see how Protestant preaching repeats the same pattern: You're supposed to be confident in your salvation, but not flatly complacent. But because many ministers saw their flocks as leaning towards the second danger, they too cranked up the terrifying visions of damnation. Did this prepare the desertion of a goodly part of their flock to humanism? I believe this to have been so ..." (Taylor (2007), 75). Denne bemærkning hos Taylor finder bl.a. belæg i det nyeste studium af danske præstesager efter reformation i Charlotte Appel og Morten Fink-Jensen, Når det regner på presten. En kulturhistorie om sogneprester og sognefolk 1550-1750 (Højbjerg: Hovedland 2009). I første omgang var det dog mere folkereligionens monistiske skæbnetro end humanismen, der blev folkeligt tilflugtssted i Danmark.

b. Jakob Rod, Folkereligion og kirke (København: Gad 1961) og "Dansk Folkereligiøsitet før og nu”, Kritisk Forum for Praktisk Teologi 9 (1982), 29-48.

c. Hans Raun Iversen, "Den danske religionspark", Gudstro i Danmark, red. Morten Thomsen Højsgaard og Hans Raun Iversen (København: Anis 2005), 103122.

d. Thyssen [1989] (1991).

e. Højsgaard og Iversen (2005).

Som filosof og idehistoriker er Taylor, hvad han selv meget vel ved og søger at tage højde for, ${ }^{21}$ bedst til at opspore og gennemtænke sekulariseringsprocessen med baggrund $\mathrm{i}$ en slags social nedsivningsteori: Det hele starter med nogle i sig selv ofte teologisk velbegrundede ændringer i den principielle tænkning omkring religion hos eliten, fx i reformationen; efterhånden får disse tanker praktisk gennemslag i form af ændringer i den kirkelige praksis og samfundets indretning og tilsidst slår de igennem i menigmands tankeverden i kraft af ændrede livsvilkår. Det er på mange måder en plausibel beskrivelse af udviklingen, selv om man må forstå ændringerne i tænkningen om det religiøse som en (webersk) katalysator snarere end som et ensidigt årsags-virkningsforhold. Taylor ved godt, at $\mathrm{fx}$ ændringer i produktionsmåden og livsformen har betydning for sekulariseringen. Hans positive pointe er imidlertid ikke blot, at der ikke er en lige vej fra 
livsformmæssige ændringer til ændringer i religiøsiteten, men at fokus i sekulariseringsanalysen må være på vilkårene $i$ den enkeltes livsorienteringssituation (og ikke på de sociologiske teorier om religionens betydning i samfundet), hvad den praktiske teologi må tilslutte sig for sit formål.

Sekulariseringsprocessen har i Taylors optik særligt fire udviklingslinier: Den mest grundlæggende er religionens 1) disembodiment, social disembeddedness og dermed hvad Taylor teologisk sigende, men uden nærmere forklaring kalder religionens excarnation (s. 613-15). I subjekternes konstitution finder Taylor samtidig 2) et skifte fra porous selves, som lader sig invadere og fortrylle af religiøse kræfter, til buffered selves, der selv kontrollerer omgangen med det religiøse. Parallelt hermed fremhæver han 3) opløsningen af det hellige i betydningen "the belief that God's power is somehow concentrated in certain people, times, places or actions" (s. 76). Til at være sekulariseret - og ikke hverken gammel- eller nyreligiøs - hører, at 4) man må tænke "den dybe sammenhæng" (ofte kaldet Gud) i ens liv indenfor en "immanent frame", hvor min "Gud” er udtryk for den måde, hvorpå lige akkurat jeg er til som et støvfnug i den store evolutionære emergens. At "hvile i Gud" er at hvile i den naturvidenskabeligt beskrivbare, personlige skæbne, som evolutionen tildeler os. ${ }^{22}$ Afgørende er det for Taylor, at sekularisering ikke blot handler om (den weberske) affortryllelse i kraft af fornuftens overtag eller subtraktion, hvor noget forsvinder, men om en transformation af det praktiske religiøse liv:

\footnotetext{
We have moved from an era in which religious life was more 'embodied', where the presence of the sacred could be enacted in ritual, or seen, felt, touched, walked towards (in pilgrimage); into one which is more "in the mind", where the link with God passes more through our endorsing contested interpretations - for instance of our political identity as religiously defined or of God as the authority and moral source underpinning our ethical life (Taylor 2007, 553f.).
}

Med denne konklusion på de fire hovedlinier i forståelsen af sekulariseringsprocessen kommer Taylor tæt på baggrunden for dagens (post)moderne håndtering af behovet for ritualisering, som vi skal vende tilbage til nedenfor. I Danmark forudsættes det i dag på den ene side, at vi tænker sekulært, på den anden side, at vi går ind for og ved givne lejligheder frekventerer - en statsstøttet folkekirke, der på den ene side taler religiøst om Gud som Fader, Søn og Helligånd, men som på den anden side også har den funktion at reflektere og for

22. Jf. fx Thomas Söderqvist, "At leve med en naturvidenskabelig Gudstro", Dansk Kirkeliv (2004), 29-35. 
så vidt problematisere religionen, så man kan være nogenlunde sikker på, at de folkekirkeligt konfirmerede unge aldrig bliver religiøst motiverede radikalister. ${ }^{23}$ En sådan dobbelthed både hos den enkelte og $\mathrm{i}$ kirkens virksomhed svarer til en anden dobbelthed, som Taylor har sans for, når han peger på, at tanken om og længslen efter transcendens, som sekulariserede mennesker næsten besværgende søger at undgå, så at sige er indbygget i den menneskelige tilværelse:

Transcendence escapes embodiment in the sense that, on the one hand, I do not know if my present way of reaching God, understanding of God or whatever, is inadequate. It does not do justice to reality and I hope that I will somehow be able to climb further. But, on the other hand, there is no way in which I will have a relation to God which is not in some way or the other embodied. It is just like when I am writing a poem and I am trying to find the right word and I feel all the time this is not the right word, but what I am trying to do is to find the right word, so there is no way for me getting that written without finding the word. ${ }^{24}$

Om Guds forhold til mennesker aldrig så meget gestaltes på Guds vilkår, så gestaltes menneskers forhold til Gud på menneskets vilkår: forholdet må nødvendigvis tage udgangspunkt og forankres i vores eksistentielt-kropslige liv med dets faktiske rammer og ressourcer af fx rituel og sproglig art. Det er her ambivalensen trives i et evigt krydspres mellem immanente og transcendente tolkninger, hvor samme nyhelbredte patient fx kan skifte mellem at sige: "Lægen har gjort mig rask", "Det var et rent mirakel" eller "Jeg blev rask, fordi jeg fokuserede og tænkte positivt: I am worth it!”.

Filosofisk stiller Taylor den religiøse tankegang i fx kristendommen på linie med især humanismen og naturalismen som en mulig tolkningshorisont. ${ }^{25}$ Hans holdning til kristendommen minder således lidt om det syn, som hans europæisk-kontinentale counterpart, Jürgen Habermas, gentagende gange har udtrykt på sine ældre dage. Hvor Taylor primært fokuserer på religionens kropsligt-eksistentielle betydning, ser Habermas, der personligt tror på moderniteten, på kristendommen som en historisk kraft i europæisk kultur:

In the West Christianity not only fulfilled the initial cognitive conditions for modern structures of consciousness ... Egalitarian universalism,

23. Således Kristeligt Dagblads leder 24.11.08 som kommentar til en undersøgelse, der viser, at konfirmander bliver mindre troende i løbet af konfirmationsundervisningen, jf. Leise Christensen, "Hvad mener konfirmanderne om konfirmationsforberedelsen?”, Kritisk Forum for Praktisk Teologi 115 (2009), 15-25.

24. Leòn de Lomo \& Bart van Leeuwen, "Charles Taylor on Secularism. Introduction and Interview”, Ethical Perspectives 10 (2003), 78-86 (84).

25. Se Raffnsøe-Møller i Taylor (2002), 16-24. 
from which sprang the ideas of freedom and social solidarity, of an autonomous conduct of life and emancipation, of the individual morality of consciousness, human rights and democracy, is the direct heir to the Judaic ethic of justice and the Christian ethic of love. This legacy, substantially unchanged, has been the object of continual critical appropriation and reinterpretation. To this day there is no alternative to it. And in light of the current challenges of a postnational constellation, we continue to draw on the substance of this heritage. Everything else is just idle postmodern talk. ${ }^{26}$

\section{Hvornår blev danskerne sekulariserede?}

Som antydet i skemaet ovenfor har sekulariseringsprocessen haft et særegent forløb i Danmark. Lad os kort trække nogle hovedlinier op omkring den evangelisk-lutherske kirkes udvikling og indflydelse i Danmark. Op til 1800-tallet bestyrede kirken og presterne (og det teologiske fakultet) den pastorale tolkningsmagt, sådan som den var rammesat i fx Moselovens bestemmelser i Danske Lov af 1683. ${ }^{27} \mathrm{Ef}-$ terhånden - mest massivt med konfirmationsundervisningen fra 1736 og skoleloven af 1814 - blev der også ressourcer til en systematisk indsats for, at den ydre politik kunne omsættes til indre liv i form af refleksion og selvkontrol, gennem socialisation og undervisning. På den måde lod kirken sig bruge til at søge at gennemtvinge et religiøst indbygget statsligt magtvæsen, der kunne styrke kongens riger under angivelse af, at man fremmede evangelisk-luthersk kristendom. ${ }^{28}$ Den officielle tolkningsramme var sat, men selv om den ofte kunne gennemtvinges, fx så forbryderne antog den og angrede på skafottet, ${ }^{29}$ er det yderst tvivlsomt, om danskernes store flertal i særlig grad var evangelisk-lutherske kristne under enevælden. Men de var kun sjældent noget andet, for der var ikke mange andre bud på religiøs tolkning - bort set fra folkereligionens "Gud, dyd og udødelighed", som kan spores tilbage til 1800-tallets begyndelse (Rod 1961). Det er under alle omstændigheder forsimplet, når den luther-

26. Jürgen Habermas, Times of Transition (Cambridge: Polity Press 2006), 150f. Se videre Jürgen Habermas og Joseph Ratzinger, Fornuft og religion. Sekulariseringens dialektik (København: Hovedland 2006).

27. Tyge Krogh, Oplysningstiden og det magiske (København: Samleren 2000).

28. Niels Reeh, Religion and the State of Denmark. Ph.d.-afhandling. (Det Humanistiske Fakultet, Københavns Universitet, 2006).

29. Jf. Struensee (se Jens Glebe-Møller, Struensees vej til skafottet. Fornuft og åbenbaring $i$ oplysningstidens København (København: Museum Tusculanums Forlag 2001), modsat Balle-Lars (se J. E. Gjellebøl, Spildte Guds Ord på Balle-Lars (Næstved, 1861, genudgivet Århus: Wornianum 1971). 
ske to-regimente-lære anses for at have adskilt religion og politik. Den var - og er? - fuldt så meget et politisk styringsredskab. ${ }^{30}$

Afgørende for Luthers kristendomsforståelse er det eksistentielle møde med og erfaring af Guds nåde pro me. Som den eneste af de danske reformatorer deler og fastholder Hans Tausen denne pointe. Allerede med Peder Palladius - og gennemført med ortodoksien bliver dansk lutherdom præget af Melanchtons læresystem langt mere end af Luthers eksistentielle erfaringsteologi. Læren bemægtigede sig livet, den statsligt fastsatte rettroenhed havde ikke brug for almindelige menneskers erfaringer. Hvis de holdt sig til den ortodokse praksis, kunne de godt få lov at tænke uortodokst, blot de ikke talte højt om sådanne tanker. Sporadisk med pietismens og ganske massivt med vækkelserne tog erfaringskristendommen teten igen, men nu skemasat med krav om en bestemt form for omvendelsesoplevelse med tilhørende tro og livsførelse. Man kan anskue vækkelserne som udtryk for "kristning", for så vidt en tredjedel af Danmarks befolkning her for første gang på tur og række stod frem og bekendte en personlig erfaringskristendom - om end en noget skematisk af slagsen. Samtidig kan man - med Thyssen - se på vækkelserne som et bidrag til sekulariseringsprocessen i form af frigørelsen fra den statssanktionerede og statsintegrerende religiøsitet.

Opsummerende kan vi med hensyn til Danmark tale om tre former for historisk akkumuleret sekularisering: 1) Selv om majoriteten næppe har været specielt evangelisk-lutherske, lever de allerfleste danskere indtil 17-1800-tallet indenfor et fast, religiøst ritual- og symbolunivers. ${ }^{31} \mathrm{I}$ dag er der et stigende antal mennesker, der er $i k$ ke-troende i religiøs henseende, $\mathrm{fx}$ ateister og agnostikere. 2) Et endnu mere gennemgående træk er bevægelsen fra en stærk - ubetinget og måske relativt ureflekteret - tro til en svag - betinget og problematiseret - tro (Højsgaard og Iversen 2005). 3) Endelig er der sket en høj grad af transformation $i$ savvel den rituelle praksis som troens symbolske udtryk - som forventeligt med skiftet over landbrug via industri til service som den overvejende produktionsmåde. Vi skal ikke længere finde ud af, hvem Gud er for os inden for et givet fællesskab under samme hellige tronhimmel. Vi spørger måske heller ikke længere, hvad Gud er i de midlertidige fællesskabers sektoriserede univers. Vi spørger snarere, hvor Gud er - når vi opsøger stadigt nye "quality places" for

30. Jf. Niels Henrik Gregersen,"Religion i det offentlige rum. Luthers to-regimentelære mellem privatisering og governmentalisering", Presteforeningens Blad, 34-35 (2008), 737-745 og 767-772.

31. Jens Glebe-Møller, "Hvis Gud ikke eksisterede, måtte vi opfinde ham”, Gudløs! Religionskritik i dag, Malene Busk og Ida Crone red. (København: Tiderne Skifter 2008), 43-60. 
at søge orientering - og fullness - i nye relationer og på nye arenaer. 32

På den ene side blev sekulariseringsprocessen forsinket i Danmark, hvor den statskirkelige enevælde ikke gav megen plads til tankerne om civilisation og humanisme frigjort fra religion. Antageligt er det de passiviserende sider ved samme statskirke, der på længere sigt førte til, at kristendommen stod relativt svagt, da religionsfriheden langsomt blev indført for alle, inkl. kirkens medlemmer, så Danmark sammen med Sverige nu fremstår som de mest sekulariserede lande i verden i dag (Davie 2002). Samtidig har de seneste års relativt hurtige omstilling fra sektoriseret industrisamfund til fluktuerende servicesamfund nedbrudt en lang række af de barrierer mod religiøs praksis og tankegang, som dominerede billedet under industrialismen.

Når vi stiller tingene sådan op, tager vi primært udgangspunkt i religion som tilslutning til et religiøst symbolunivers, som er svækket og ændret i sekulariseringsprocessen. Ser vi derimod primært på den rituelle praksis, er udviklingen langt mindre markant. Danskerne har aldrig brugt deres kirker som synagoger, men som templer - og det gør de stadigvæk. Selv om fx deltagelsen i søndagsgudstjenesten, der i den store kirketugtstid i 1700-tallet og vækkelsernes kulmination omkring år 1900 toppede med omkring $10 \%$ af befolkningen, nåede ned på ca. 2 \% omkring 1970, er den samlede nedgang ikke overvældende. ${ }^{33}$ Med de åbne kirker, natkirker etc. i dag er vi på vej tilbage til en kirkebrug, som i mangt og meget ligner den, der kendtes især omkring domkirkerne i middelalderen. ${ }^{34}$ I kraft at dagens uendelige udbud af alternative kulturelle og religiøse praksisformer kan man selvsagt ikke forvente, at den samlede kirkebrug når samme omfang som i middelalderen.

32. Anders Bäckström m.fl., Religious Change in Northern Europe. The Case of Sweden (Stockholm: Verbum 2004). Jeg har skitsevist overført de vægtige resultater af den svenske analyse til danske forhold i "Fluktuerende menigheder - nye arbejdsvilkår for folkekirken”, Dansk Tidsskrift for Teologi og Kirke 2 (2009), 43-54.

33. Hans Raun Iversen, "Hvad vi ved om kirkegang", Grundtvig, folkekirke og mission (København: Anis 2008), 217-226.

34. Min tolkning af udviklingen i Danmark svarer i store træk til Graeme Smiths syn på udviklingen i England i A Short History of Secularism (London: I.B. Tauris 2008): Alle forskelle i samfundsindretning, levevis og tolkningshorisonter til trods ligner vor tids kirkebrug med et mindretal af faste og et stort flertal af sporadiske kirkebrugere middelalderens. Vi er for så vidt kommet "back to normal" efter den usædvanlige missionariske og moralske indsats for menighedskristendom i 1800-tallet. 


\section{Kristendommens indlejring i dansk mentalitet i dag}

Til denne særlige danske udgave af en lang almen, vesteuropæisk sekulariseringsproces, kommer den særlige indlejring af såvel sekularisering som religion/kristendom i den særlige danske mentalitet. I forskellige faser har kristendommen 1) dannet grundlag for samfundsopbygningen (fra 975-1975), 2) været eksproprieret af staten til brug for dennes økonomiske, infrastrukturelle, sociale og idemæssige opbygning (især siden 1536), 3) udtømt sig selv og sine kræfter på næsten kenotisk vis i samfundet (typisk både i rationalismen og vækkelserne, især med grundtvigianismen og Københavns Indre Mission), mens man i dag kan tale om, at 4) kristendommen og folkekirken som en slags gidsel for den symbolpolitiske "danskhed", både på det politiske plan og i den folkelige forståelse, hvor man i Danmark kan kalde sig kristen, hvis man kun har én kone ad gangen. Omkring $70 \%$ betegner sig som kristne, mens $82 \%$ er medlemmer af folkekirken. ${ }^{35}$

Ifølge I hjertet af Danmark (Gundelach, Iversen og Warburg 2008) er gammeldanskernes mentalitet præget af 1) glæde over Danmark, 2) tryghed, tillid, lykke og (selv)tilfredshed, 3) kollektivt orienteret individualisme, 4) vægtning af lighed, frihed og lav magtdistance, 5) forskellighedernes indordning under fællesskabet, 6) ønsket om "at være sig selv" og 7) adgangen til at være dansk på mange måder. Mentaliteten reproduceres gennem samfundets bærende institutioner: familien, skolen, flexicurity-ordningen, dagliglivet og civilsamfundet. Som et bagtæppe med mange stærke tråde til mentaliteten finder vi danskernes religion: den forbeholdne gudstro, den gyldne middelvej og sansen for, at "der da må være en mening med det hele". Tæt sammenvævet med religionen finder vi nationen, som danskerne er knyttet til gennem bestemte handlinger, meget lidt gennem en særlig viden, men ganske stærkt gennem en følelse af identifikation. Det er alt sammen meget godt, men også noget af en udfordring, teologisk som politisk.

Kristendommen og det folkelige forhold til folkekirken fungerer meget parallelt med forholdet til nationen og "danskheden": Det bæres af ret meget being (fornemmelse for tilhørsforhold), men mindre knowing (kundskaber) samt sporadisk doing (praktisk deltagelse i ritualer etc.). I praksis er folkekirkeforholdet og "danskheden" viklet sammen og ofte uadskillelige, p.g.a. kristendommens historiske be-

35. Jf. Hans Raun Iversen, "Kristendommen i og bag det danske samfunds opbygning og mentalitet", Tidsskrift om Islam og Kristendom 1 (2009), 18-29. Især for de to første punkters vedkommende kan der henvises til bl.a. Tim Knudsen, Fra enevalde til folkestyre. Dansk demokratihistorie indtil 1973 (København: Akademisk Forlag 2006), 51-58. 
tydning for samfundsopbygning og mentalitet i Danmark. Hertil kommer genopblomstringen af en særlig civil religion (samfundsborgerskabslegitimerende religion), som findes dels inden for og dels uden for folkekirken. Civilreligionen er indtil videre så historisk præget af kristendommen, at den har vanskeligt ved at inkludere fx muslimerne, som en civilreligion ideelt gør det - fx i USA og Tanzania. ${ }^{36}$

Mellem Taylors felter for "autenticitet" og "betydningshorisonter" ligger et stort historisk forankret felt af "mentale mønstre i vekselvirkning med bærende institutioner." Antageligt er forholdet det, at såvel vores fornemmelse for "autenticitet" som vore "betydningshorisonter" filtreres gennem og lever på betingelse af, hvad der er på spil i "de mentale mønstre i deres vekselvirkning med bærende institutioner”. Når vi ritualiserer eller reflekterer religiøst, er vi fortsat danskere mentalt set! Spørgsmålet er derfor, hvor religion, kristendom og kirke hører hjemme i billedet: Som en helt indlejret del af de mentale mønstre, som et bagtæppe for samme og/eller som bidragyder til "autenticitet" og "betydningshorisonter" med en vis frihed i forhold til de foreliggende "mentale mønstre i deres vekselvirkning med bærende institutioner"? For at komme videre med det spørgsmål vender vi os mod en klargøring af det religionsbegreb, der anlægges hos Taylor og i dette bidrag.

\section{Religion som symboler, der ritualiseres, eller ritualisering, der symboliseres}

Så sent som på et af opstartmøderne for Københavns Universitets satsningsområd Religion i det 21. arhundrede i foråret 2004 var der almindelig tilslutning til symbolantropologen Clifford Geerts religionsdefinition:

En religion er (1) et symbolsystem, som medvirker til (2) at etablere kraftfulde, gennemtrængende og langtidsvirkende følelser og motiveringer i mennesker ved (3) at formulere begreber om eksistensens generelle orden og (4) at iklæde disse begreber en aura af en sådan faktualitet at

(5) følelserne og motivationerne synes enestående virkelige. ${ }^{37}$

Ligesom den teologiske tradition finder Geerts religionens fokus i det religiøse synbolsystem. Flere nyere ritual- og religionsteoretikere frem-

36. Margit Warburg: "Dansk civilreligion i og uden for folkekirken", Kritisk Forum for Praktisk Teologi 109 (2007), 48-66.

37. Her citeret efter Armin Geertz, "Hvad er religion?", Kritisk Forum for Praktisk Teologi, 91 (2003), 2-10 (4). 
hæver i dag, at religion ikke primært er funderet i et teologisk symbolog normsystem, men et kompleks af rituelle praksisformer. ${ }^{38}$ Fokus flyttes fra at se på religion som et religiøst symbolsystem, der evt. kan "opføres" i ritualer, til at se på religion som menneskets (eksistentielt og kropsligt betingede, evt. kollektivt gennemførte) ritualisering, hvor den enkelte gor bestemte ting og - ud fra de foreliggende muligheder samtidig evt. tyder og tilegner sig forskellige dele af et tilstedevarende religiøst symbolsystem. Illustrative, aktuelle eksempler på "almindelige" menneskers individuelle ritualisering i kollektiv sammenhæng er gaderitualer a la dem ved prinsesse Dianas død, stillegudstjenester i fængsler, brugen af åbne kirker og natkirker, kirkelige handlinger samt Rigshospitalets funktion som byens største bedehus. ${ }^{39}$

Centralt står her Martin Riesebrodts historiske argumentation for, at "religion" i betydning ritualer altid har været til stede og kontrolleret af magthaverne, hvor der har været mennesker. Ritualer indgår ofte, men ikke nødvendigvis i et symbolmiljø, hvorfra mennesker kan tyde og tilegne sig forskellige former for mening, men denne funktion er sekundær $\mathrm{i}$ forhold til den basale ritualisering (Riesebrodt 2007). Øjensynligt springer ritualiseringsbehovet ud af det simple forhold, at vi som mennesker har den skæbne, at vi hver især må være i vores eget skind, hvorfor vi kropsligt-eksistentielt må søge ud over os selv til fællesskab med de andre - og muligvis med Gud og naturen - for at ophæve vores ubodelige isolation i hver vores krop. Vejene til et sådant fællesskab er mange (samtale, kulturel udfoldelse, familiestiftelse, sex, sport, kropstræning, healing etc.), men ritualiseringen melder sig åbenbart med stor styrke som én af dem.

Fra Feuerbach over Freud til moderne teologi ${ }^{40}$ har der været filosoferet meget over, hvad moderens livgivende nærvær betyder for det lille barn: Hvad repræsenterer og symboliserer moderen (og faderen)? Er det ikke her i en meget tidlig fase, grundlaget for gudsbilledet dannes? Det er og bliver alt sammen mere eller mindre begavet spekulation. Ubetvivleligt er det derimod, at moderen for barnet - før som efter fødslen - leverer kropskontakt, tryg omgivelse og god næring. En mor er ikke nødvendigvis en Gud, men afgjort en krop. På utallige måder søger mennesker senere i livet, hvor jeg'et er mere selvstændig-

38. Jette Marie Bendixen Rønkilde, "Kroppen som troens spejl - hen imod en teologisk somatologi”, Dansk Teologisk Tidsskrift (2008),188-203.

39. Peter la Cour, "Existential and religious issues when admitted to hospital in a secular society: Patterns of change", Mental Health. Religion and Culture, Vol 11, 2008, p. 769-782.

40. Se fx Wolfhart Pannenberg, "Religion and Human Nature", The Historicity of Nature: Essays on Science and Theology (Philadelphia: Templeton Foundation Press 2008), 75-86. 
gjort efter trodsalderen, tilbage til en lignende tryghed via kroppen, som den kendtes i symbiosen med moderen - for at holde sammen på selvet via kroppen. Her melder det velkendte ritual sig med styrke.

Hvad enten nu akkurat dette forhold eller noget andet er afgørende, så beholder Riesebrodt ret i, at religion primært er kropslig praksis. Fodbold har (som musikudøvelse og meget andet) mange konnotationer af symbolsk og samfundsmæssig art - tænk blot på "fodboldenglen" og "tredje halvleg". ${ }^{41}$ Men uden den kropslige og eksistentielle udfoldelse på fodboldbanen, var der ikke meget ved "fodbold". Uden ritual praksis bliver religion også en meget tynd affære. Det gælder her, som det for Luther gælder med hensyn til nadveren: Det er galt, hvis nadveren bliver til en magisk ex opera operato, men det er lige så galt, hvis vi ikke bruger nadveren, for den virker kun i brugen som et opus operantis. "Jesus siger: 'Gør dette...!' Han vil virkelig have det gjort og ikke undladt eller foragtet". ${ }^{42}$

Følger vi denne tankegang, må den praktiske teologi (og kirkens opmærksomhed) justere fokus fra "kirkens kommunikationsformer" med deres kognitive teologiske indhold som det dominerende i retning mod "menneskers rituelle praksis", hvis vi skal komme tættere på det (religiøse) liv, mennesker lever i og udenfor folkekirken. I stedet for at tale om mennesker ( $\mathrm{fx}$ pårørende ved kirkelige handlinger) som "forbrugere på et marked", hvor "enhver sammensætter sin egen religion”, må man begynde med at forstå det eksistentielle og kropslige behov for ritualisering som basalt og uden bagtanker om "selviscenesættelse" etc. Noget andet er, at medbragte fikseringer, blokeringer, fordomme og konventioner kan bryde ind og forstyrre ritualiseringen - allerede i planlægningsfasen, som folkekirkepræster $\mathrm{fx}$ kan opleve det i begravelsessamtalen.

\section{Sekulariseringsprocessens resultat}

Med baggrund i Pontoppidan Thyssens forståelse af sekularisering som frigørelsen fra "den statsintegrerede, almindeligt accepterede statsinstitutionelle religiøsitet" og Taylors analyse i A Secular Age kan vi sammenfatte sekulariseringsprocessens foreløbige resultat i Danmark i fem punkter: 1) Der er vage og brudte tolkningshorisonter, ${ }^{43}$

41. Hans Jørgen Nielsen, Fodboldenglen (1982) og Tage Skou-Hansen, Tredje halvleg (1971).

42. Martin Luther i Fortalen til Den Lille katekismus.

43. Det er unikt at møde mennesker, der i dag tolker alle erfaringer og udfordringer ud fra en frelseshistorisk og gudstjenesteteologisk helhedsforståelse, sådan som 
2) der er derfor næsten altid ambivalens i tydningerne, 3) der er et stort autenticitetsbehov, 4) der er en stærk erfaringscentrisme - vi kan kun tro, hvad vi mener at have erfaret, ${ }^{44}$ og 5) der er hyppige blokeringer omkring, hvad man mener at have oplevet som autentisk og erfaret, så man lukker af for alternative tolkninger.

Der er her tale om en historisk egenartet situation, som handler om meget andet end "svind i religion", at "sekularisering" ikke uden videre er den mest præcise betegnelse at bruge om situationen. Positivt sagt er der tale om en situation med fritstillet, individuel, kropslig og eksistentiel ritualiserings- og symboliseringspraksis, alt imens denne praksis foregår inden for en ganske stærk fælles mentalitet og religionspark (Iversen 2005).

Netop kombinationen af den stærke individualisering og de stærke fællestræk er karakteristisk for situationen. På den ene side holder vi os tilbage med religiøs sprogbrug ("Guds fred i stuen" og bordbøn forudsætter en form for konsensus), ligesom vi end ikke føler os forpligtede på at videregive egne religiøse holdninger og praksisformer til vore børn. På den anden side synes det også at gælde, at jo mere sekulariseret $-\mathrm{i}$ betydningen fjern fra kirkelig praksis - situationen bliver, jo mere umætteligt bliver øjensynligt behovet for ritualiseringer. 45

Selv om mennesker i dag - akkurat som i folkereligionens tid - ofte har deres eget tilsæt ( $\mathrm{fx}$ astrologi og reinkarnation) til den fælles "kristendom", fører individualiseringen til homogenisering. Hed det tidligere "Gud, dyd og udødelighed", hedder det i dag "Gud elsker dig, Jesus forstår dig, og du skal nok blive rask". 46 Det er en sådan teologisk minimaliseret, mild kristendom, der skiltes med overalt. Men netop dette, at udgangspunktet er individet, mens udbudet er standardiseret, betyder også, at der ikke er noget incitament til troskab overfor den enkelte kirke, for man kan givetvis let i selv samme nabolag finde et tilsvarende udbud, som endda forekommer mere "autentisk". I samme retning trækker den fysiske mobilitet og migrationen samt det religiøse udbud på nettet og i de fælles elektroniske medier (Hervieu-Lèger 2006).

den snart 90-årige biskop Henrik Christiansen gør det (Tro og eksistens, DR1, søndag den 16. november 2008).

44. Jf. Gundelach, Iversen og Warburg (2008), $243 f$.

45. Sådan kan man tolke et omfattende svensk lokalstudie: Guds närmaste stad? En studie $i$ religionernes betydelse $i$ ett svenskt samhälle $i$ början av 2000-tallet, red. Kajsa Ahlstrand och Göran Gunner (Stockholm: Verbum 2008).

46. Hervieu-Lèger, Daniéle, "In Search of Certainties: The paradoxes of Religiosity in Societies of High Modernity", The Hedgehog Review 1-2 (2006), 59-68. 


\section{Praktisk teologisk vurdering}

Kan man være kirke i en sådan virkelighed, der på engang er frygteligt individualiseret og grusomt standardiseret? Det er næppe hverken meget værre eller bedre end i tidligere tider. Men det er anderledes. Forudsætningerne hos menneskene er anderledes i kraft af sekulariseringsprocessens resultater, hvortil kommer, at den kirkelige pastoralmagts autoritet til at lede mennesker til liv og helse gennem individualiseret brug af de personlige relationer er splittet ud på mange nye "hyrder". Der er prædike- og skriftestole overalt. ${ }^{47} \mathrm{Nu}$ som før, og måske endnu mere nu end før, gælder det imidlertid: Vil man et menneske noget, må man "ganske nøiagtigt finde det Sted, hvor den Anden er, og begynde der". 48

Sekulariseringsanalysen er vigtig, men det er lige så vigtigt at tænke teologisk om situationen. Teologisk kan man tænke på ritualiseringsbehovet som udtryk for Augustins urolige hjerte, der søger hvile hos Gud og dermed som en del af menneskers medskabte gudbilledlighed. Eller man kan se det som udtryk for, at Helligånden som sendt til mennesker i verden virker i menneskers hjerter, så de sendes til at møde kirkens udtryk for den Kristus, hvis signatur de bærer fra skabelsen. Dermed accepterer man sekulariseringen som et vilkår, men ser samtidigt på den fortsatte religiøse vitalitet som et tilsvarende vilkår. Kan man det? Det afhænger af to forhold:

For det første afhænger det af, hvordan man vurderer religion politisk. I en tid med angst for, at religionen skal styre politikken, må det siges, at religionen var der overalt før, og at den bidrog overvejende positivt til udviklingen af, demokratiet i Vesten. Det var de kristeligtkonservative partier, der var med til at sikre demokratiet i Vesteuropa efter anden verdenskrig. Og det var kristeligt-politiske kræfter, der stod bag den første Rom-traktat mellem Tyskland, Italien, Frankrig og Benelux-landene. Efter den westfalske fred efter 30-årskrigen (1618-1648) brugte staterne med cujus regio ejus religio-princippet religionerne til at opbygge og støtte nationalstaterne og ikke omvendt, ${ }^{49}$ - som allerede Harald Blåtand og ikke mindst Christian III gjorde det. Religion fylder som nævnt meget i den politiske debat,

47. Mads Peter Karlsen, Pastoralmagt - om velfardssamfundets kristne arv (København: Anis 2008).

48. Søren Kierkegaard, "Synspunktet for min Forfatter-Virksomhed", Samlede Verker 18 (København: Gyldendal 1964), 98.

49. Jf. Josè Casanova, "Religion Challenging the Myth of Secular Democracy", Lisbet Christoffersen m.fl. red., Religion in the 21st Century. Challenges and Transformations (London: Ashgate 2010). Flere indlæg i samme bog argumenterer ad tilsvarende baner. 
men ikke i hverdagslivet i Danmark. Politikerne bruger religionen, snart som skydeskive, snart som støttestav, jf. fx de regeringsbeordrede civilreligiøse national-gudstjenester efter terrorhandlingen 11. september og flyulykken i oktober 2001 og tsunamien 2004.

Det skal medgives, at den religionspolitiske situation har sin særlige baggrund i "religionernes tilbagekomst" i bestemte dele af den verdenspolitiske arena med 1) konservative religionstyper, der kom til politisk magt fra 1979: Khomeini i Iran, Moral Majority i USA, den polske kardinal Karol Wojtyla blev pave Johannes Paul II, og Likudpartiet i Israel, 2) murens fald i 1989, hvor den kolde krigs polaritet mellem øst og vest blev afløst af forestillingen om de religiøst funderede civilisationers sammenstød, 3) muslimske grupperingers spektakulære fremtræden i konfrontationer a la 11. september 2001 og Cartoon Crises 2006 og 2008. Religionernes tilbagekomst på den politiske scene modsvares ikke af en markant religiøs oprustning i befolkningerne. De store krige og folkemord i den 20. århundrede skyldes heller ikke-religiøse kræfter. Fodboldvold overgår religionsvold med flere længder. Intet taler for, at religion som sådan er politisk farligere end andre kulturelle fænomener. ${ }^{50}$

For det andet afhænger det af, hvordan man vurderer religion og sekularisering teologisk. Indtil de sidste årtier af det 20. århundrede var holdningen til religion overvejende negativ og holdningen til sekulariseringen tilsvarende positiv i protestantisk teologi, selv om man dog fremhævede, at der måtte skelnes mellem den teologisk legitime frigørelse fra religion (Säkularisierung) og sekularisering som ideologi eller politisk program (Säkularismus). ${ }^{51}$ Ikke blot i den nye ateismedebat, men også i det politiske liv er der i dag tendenser til, at sekularismen absolutiseres - og det så langt, at det med føje kan hævdes, at konflikterne mellem religionerne er mindre farlige end konflikterne mellem religiøse og sekularistiske positioner. ${ }^{52}$

Der er fortsat protestantiske teologer, der lægger hovedvægten på en positiv tolkning af sekulariseringen. Et vigtig udgangspunkt er Dietrich Bonhoeffers radikale krav om a-religiøs kristendom. Ud fra en modernistisk prognose om, at vi går en religionsløs tid i møde, fordrer han en religionsfri, kristen praksis. Fronten er imod enhver

50. Jf. Rune Engelbrecht Larsen, Oplysning og tolerance - arv og aktualitet (Århus: Aarhus Universitetsforlag 2009).

51. Jf. Friedrich Gogarten, Verhändnis und Hoffnung der Neuzeit. Die Säkularisierung als Theologisches Problem (Stutgart: Friedrich Vorwerk Verlag 1953).

52. Mark Juergensmeyer, Terror in the Mind of God: The Global Rise of Religious Violence. (Berkeley: University of California Press 2003). Jeg har overvejet tesen i forhold til den danske sammenhæng i "Secular Religion and Religious Secularism", Nordic Journal of Religion and Society 2 (2006), 75-92. 
form for dualisme: Den kristne kan og skal tjene Gud (udelukkende) ved at tjene menneskene $\mathrm{i}$ den nuværende tid. Sådan kan man leve "uden Gud, overfor Gud”. Tilsvarende er kirken kun kirke, når den er kirke for andre. Først når mennesker opgiver den religiøse påberåbelse af Gud til at lukke tilværelsens huller med, er det muligt at lade Gud være herre i hele tilværelsen. ${ }^{53}$

Modsat Bonhoeffer nægter den postmoderne bevægelse Emerging Churches i dag at betragte noget som helst som sekulært, uden for Guds område. Det sker imidlertid ud fra teologiske holdninger, som ligner Bonhoeffers: ${ }^{54}$ Man siger nej til alle dualismer mellem: krop/ sjæl, offentlig/privat, sekulært/sakralt, verden/kirken, man vil møde Gud midt i livet, ikke kun ved grænserne, kristendommen må aldrig blive en flugt fra verden, troen må leves inkarnatorisk i forhold til vor tid og spiritualiteten må være holistisk, ærlig over for Gud. Etsi deus non daretur hos Bonhoeffer erstattes af "som om Gudsrige er i frembrud" hos Emerging Churches, der mener, at kristne i bogstaveligste forstand må kunne agere kirke når som helst og hvor som helst.

Heroverfor står der en teologi, der kæmper for fastholdelsen/genoprettelsen af kirkerummet og dets ritualer som et alternativt, sakralt rum - præget af alt det religiøse, som sekulariseringsprocessen har fjernet fra hverdagen. ${ }^{5}$ Ifølge Mircea Eliade findes der på tværs af alle samfund - tydeligst i arkaiske samfund - et fænomenologisk beskrivbart skel mellem sakralt og profant, helligt og sekulart. Dette skel hører med til religionen, der ifølge Eliade er et autonomt fænomen, der må respekteres som sådan. ${ }^{56}$ Er der en sammenhæng mellem den 'krænkelse af det sakrale', 57 der foregår, når man fx klapper efter prædikenen, og den reformatoriske tendens til at se alt helligt, inkl. sakramentet, som intet $\mathrm{i}$ sig selv, men kun henvisning på evangeliets budskab? Når religionen går fra kulten til bevidstheden alene, bliver religiøs tale til tale om religion, fordi man ikke er parat til at gå ind i religionen. Reformationen var én stor bestræbelse på at "putting order into society", afskaffe det uordentlige (karnevalet) og regulere det hellige, siger Taylor $(2007,614)$. Slipper mennesker de religiøse fe-

53. Dietrich Bonhoeffer, Min tid er dine hender. Vennebreve og teologiske refleksioner 1943-44 (København: Aros Forlag 2006).

54. Eddie Gibbs og Ryan K. Bolger, "Transforming Secular Space", Emerging Churches (London: SPCK 2005), 65-88.

55. Jf. Bent Flemming Nielsen, "Kirken som rituelt rum", Pastoralteologi, red. Helle Christiansen og Henning Thomsen (København: Anis 2001), 83-96.

56. Mircea Eliade, Helligt og profant - om religionens vasen (Frederiksberg: Det lille forlag 1993).

57. Søren Ulrik Thomsen, "Pro Ecclesia", Kritik af den negative opbyggelighed. 7 essays af Frederik Stjernfelt \& Søren Ulrik Thomsen (København: Vindrose 2005), 151-197 (183). 
ster, som de i stort omfang har gjort det i Nordeuropa modsat Sydeuropa, giver de sig profaniteten i vold. Hvor fx den indiske kultur tenderer mod at lade det sakrale være dominerende, er tendensen den stik modsatte i protestantismen.

Hvordan kan man komme videre i forhold til disse positioner? Igen kun ved at tænke teologisk. På den ene side er det denne faktisk foreliggende verden, Gud elsker, ligesom det er til denne verden, Helligånden er sendt. Om noget gør inkarnationen det klart, at det hellige, Guds virkes sted, er midt i det almindelige menneskeliv. På den anden side viser både bibelen, en luthersk sakramentlære og kirkens erfaring fra fx Tyskland, hvor man i dag kun finder et kristent gudsbillede hos mennesker, der går i kirke, at Taylor har ret i, at kristendommen ikke kan undvære det hellige i betydningen "the belief that God's power is somehow concentrated in certain people, times, places or actions" (s. 76). Udfordringen er for så vidt at give plads til en kropslig-eksistentiel omgang med "det hellige", der betyder, at "det hellige" i form af Kristustro kan tages med hjem, fordi det sidder i kroppen. Hvordan det kan lade sig gøre, behandles i Anna Marie Aagaards kommende bog om Hellighed. 58

Vigtige punkter ser ud til at være: 1) Vi må have "ledebånd", alt som vi gå ${ }^{59}, 2$ ) a.h.t. svage flyvere, der har brug for medvinden fra medflyvere, og "skyggesangerne", der har brug for akkompagnement fra menigheden, må der være følgeskab i den fluktuerende deltagelse i ritualerne, og 3) endelig er det afgørende, at kroppene kommer med. "Kun kroppen frelser sjælen", citerer Anna Marie Aagaard Rowan Williams for at sige. Hun tilføjer: "...det er $i$ sproget, i den kirkelige praksis, vi lærer hvad der er udenfor sproget” (kap. 2, s. 43). Lad os derfor slutte med to eksempler på muligheder for kirkelig praksis: Ritualer og sjælesorg.

På ritualbrugens område - tydeligst i natkirkerne - er vilkåret det samme som i fx gospelkorene: Man fungerer på én og samme tid som 1) kulturel aktivitet, 2) potentiel rekruttering til en form for "fast" menighedsliv og/eller 3) menighed i sig selv. ${ }^{60}$ De åbne døre og det stærke centrum i natkirken kan praktiseres med en relationel kirkeforståelse, hvor medarbejderne møder alle med holdningen: "Kirken er din, som den er min". I kirken er alle viceværter for hinanden uanset, om man bruger kirken som synagoge, tempel eller quality place. Men det skal være tydeligt for enhver, der kommer i kirken,

58. Kapitlerne offentliggøres løbende på www.teologinet.dk

59. Jf. DDS 379,8 .

60. Mark Lewis, The Diffusion of Black Gospel Music in Postmodern Denmark, A Dissertation presented to the faculty of Asbury Theological Seminary, Wilmore, Kentucky 2008 
også i natkirken, at der er (med)kristne, der har "forberedt det til os" (Mark 14,15). Enhver der kommer, skal kunne fornemme, at de kommer til de kristnes hellige måltids sted, hvor der i dag er forberedt noget særligt for dem. Enhver, der kommer i kirken må føle sig omgivet af et tilbud - ikke en tvang, men et tilbud - af kristen tro og trøst, "omtonet af Røster, der sige: kunne du ikke have Lyst til at komme til denne dine Forældres Bekjendelse, hvormed Luther stod for Keiseren...". ${ }^{61}$

Tilsvarende gælder det i sjælesorgen. ${ }^{62}$ Sjælesørgeren må turde slippe metaforerne løs. Sjælesørgere må lære at bruge folks egne metaforer. Hvad betyder det, når konfidenten fx siger: "Mormor er min Gud"? Spørg ind til det. Det kristeligt sande er det frugtbare, ikke det dogmatisk set sprogligt korrekte. Sjælesørgeren må give kraft til den, man taler med - gennem accept og velsignelse. Det er vigtigere at give styrke til mennesker end at søge at "forklare" deres sære liv. ${ }^{63}$ Man må turde bruge ritualer, om muligt i kirkerummet - tænde lys, bede, velsigne - og hvis der spørges efter det, absolution efter det stykke livshistorie, som reelt er et skriftemål. Lav evt. et ad hoc ritual: Skriv ned, hvad der tynger og læg papiret ned i et fyldt dåbsfad, så det skrevne viskes ud! Lad mennesker klage - klag altid med og aldrig imod! Gør som grædekonerne, så der bliver grædt ud. Klage er ikke selvretfærdiggørelse eller selvgodhed, men en smerte, der skal ud. Læs salme 13: den passer perfekt til den klagende, hvis "fjende" er livssituationen! Lad enhver klage til sin Gud! Lad mennesker komme ud med dødsangst og samvittighedskvaler. Husk at det græske ord for synd (harmartìa) betyder at ramme ved siden af målet. Synden er det liv, der er blevet en ond og tyngende skæbne for mennesker. Hjælp mennesker til at leve med det, der ikke kan gøres om. Hjælp dem til at ændre det, man ikke kan acceptere - eller i hvert fald tydeliggøre det og se det i øjnene. Vi må leve med døden - men også dø med livet. Husk, at livet, som Hannah Arendt siger det, er en stadig fødsel. Og den store fødsel, der mest ligner den fysiske fødsel, er døden, som Luther siger det i Sermonen om at dø. Døden er svær, men den er også en ret glædelig dag!

61. P.C. Kierkegaard, "Af Taler i Rigsdagen fra Kierkegaards Minister-Tid 1867-68", Samlede Skrifter. Fjerde Bind, udgivet af Paul Egede Glahn og Lavrids Nyegaard (København: Karl Schønbergs Forlag 1903), 524-653 (536).

62. Det følgende beror på noter fra en øvelse med lektor Elmo Due den 20. november 2008.

63. Manfred Josuttis, Segenskräfte. Potentiale einer energetischen Seelsorge (Gütersloh: Chr. Kaiser Verlag 2000). 
Overalt gælder det, at mennesker skal inviteres til at "tage ordet $\mathrm{i}$ munden" (DDS 387,3), ${ }^{64}$ til at finde styrke i liv og død gennem deltagelse i kristen, rituel praksis, til "ved nadveren at fă opbygget vores opstandelseslegeme, det nye menneske, inden i det jordiske, dødelige legeme" 65 Der er meget at gøre her, ikke mindst gennem en genoptaget brug af nadveren som "krisemåltid", fx som en kirkelig handling for dåbsgæsterne i forbindelse med dåb og ved en lang række andre, særlige lejligheder - og når et kropsligt-eksistentielt behov tilsiger det.

64. Jf. DDS 387,3. Se videre Hans Raun Iversen, "Hvor hører vi Guds ord til os?", Grundtvig, folkekirke og mission (København: Anis 2008), 93-113.

65. Johannes Værge, Efter døden. En bog om det evige liv (København: Anis 2008), 241. 